\title{
Mengenalkan Matematika Terintegrasi Islam Kepada Anak Sejak Dini
}

\author{
Annisah Kurniati \\ Program Studi Pendidikan Matematika, Fakultas Tarbiyah dan \\ Keguruan, UIN Sultan Syarif Kasim Riau \\ Email: annisa.kurniati@gmail.com
}

\begin{abstract}
ABSTRAK. Matematika perlu diperkenalkan dan diajarkan kepada anak sejak dini. Matematika sebaiknya diperkenalkan dan diajarkan kepada anak dengan cara-cara yang menarik dan dengan memadukan dan menyelaraskan materi matematika dengan nilai keislaman. Memadukan matematika dengan nilai keislaman akan terbentuk bangsa yang tangguh, berorientasi ilmu pengetahuan dan teknologi yang semuanya dijiwai oleh iman dan takwa kepada Tuhan Yang Maha Esa.Dalam pembelajaran matematika sangat penting untuk membentuk pribadi yang berkualitas. Jika dapat mengintegrasikan Islam dari setiap konsep matematika tentunya akan lebih mudah mengembangkannya dalam setiap proses pembelajaran. Banyak cara-cara yang dapat dilakukan untuk mengajarkan matematika terintegrasi Islam kepada anak. Hal yang terpenting adalah setiap pembelajaran hendaknya memberi manfaat kepada anak.
\end{abstract}

Kata kunci : matematika terintegrasi islam, anak usia dini

\section{PENDAHULUAN}

Matematika memiliki pengaruh yang besar dalam kehidupan manusia. Disadari maupun tidak, sebenarnya seseorang tidak lepas dengan matematika. Tetapi bagi sebagian besar orang menganggap bahwa matematika merupakan mata pelajaran yang amat berat dan sulit. Salah satu penyebabnya karena kajian matematika yang bersifat abstrak.Kemampuan matematika seseorang sangat dipengaruhi penguasaan matematikanya sejak dini. Oleh karena itu, matematika perlu diperkenalkan dan diajarkan kepada anak sejak dini. 
Matematika sebaiknya diperkenalkan dan diajarkan kepada anak dengan cara-cara yang menarikdan menggunakan contoh-contoh yang konkret sehingga anak dapat dengan mudah memahami. Bermain merupakan salah satu metode yang paling ampuh dalam mengajarkan matematika.Menurut Montessori dalam Sudono dengan bermain anak akan memiliki kemampuan untuk memahami konsep dan pengertian secara alamiah tanpa terpaksa (Anggani, 1995).

Apabila matematika telah menjadi hal yang menarik untuk dipelajari, maka anak akan merasakan bahwa matematika memang merupakan bagian dari hidup karena keurgenan matematika tersebut. Agar matematika dapat dirasakan anak sebagai bagian dari hidup, setiap materi matematika yang akan diajarkan harus dapat ditunjukkan aspek-aspek tertentu yang mengandung nilai-nilai dalam kehidupan. Salah satu nilai dalam kehidupan yaitu nilai moral dan akhlak.Sama halnya dengan matematika, nilai moral dan akhlak merupakan hal yang paling utama yang harus ditanamkan kepada anak sejak dini. Nilai moral dan akhlak seseorang yang terbentuk dari hasil interbalisasi berbagai kebajikan diyakini dan digunakan sebagai landasan untuk cara pandang, berpikir, bersikap, dan bertindak (Soedjadi, 2010).Agar nilai moral, akhlak dan matematika sejalan, maka salah satu cara dalam mengajarkan anak matematika mulai dini yaitudengan memadukan dan menyelaraskan materi matematika dengan nilai keislaman.Menurut Gunawan (2012) dengan menyelaraskan dan memadukan matematika dengan nilai keislaman maka akan terbentuk bangsa yang tangguh, kompetitif, berakhlak mulia, bermoral, bertoleran, bergotong-royong, berjiwa patriotik, berkembang dinamis, berorientasi ilmu pengetahuan dan teknologi yang semuanya dijiwai oleh iman dan takwa kepada Tuhan Yang Maha Esa berdasarkan Pancasila.

Berdasarkan latar belakang masalah tersebut maka perlu dikaji bagaimana mengenalkanmatematika terintegrasi dengan Islam kepada anak sejak dini.

\section{PEMBAHASAN}

\section{Matematika dan Sifatnya}

Salah satu hal yang perlu dilakukan untuk mengintegrasikan matematika dengan Islam yaitu terlebih dahulu mengetahui apa itu matematika dan bagaimana sifatnya. Istilah matematika berasal dari kata Yunani, mathein atau manthenein yang berarti mempelajari. Kata ini memiliki hubungan yang erat dengan kata Sansekerta, medha atau widya yang memiliki arti kepandaian, ketahuan, atau intelegensia.Dalam bahasa

2 Suska Journal of Mathematics Education Vol.1, No.1, 2015 
Belanda, matematika disebut dengan kata wiskunde yang berarti ilmu tentang belajar, hal ini sesuai dengan arti kata mathein pada matematika (Nasution, 1982).Matematika sendiri didefinisikan sebagai ilmu tentang bilangan, hubungan antara bilangan, dan prosedur operasional yang digunakan dalam penyelesaian masalah mengenai bilangan (Alwi, 2002).Selain itu, masih banyak definisi matematika, diantaranya yaitu matematika adalah ilmu tentang bilangan dan ruang. Matematika adalah ilmu tentang besaran (kuantitas). Matematika adalah ilmu tentang hubungan (relasi). Matematika adalah ilmu tentang bentuk (abstrak). Matematika adalah ilmu yang bersifat deduktif. Matematika adalah ilmu tentang struktur-struktur yang logik (Abdusysyakir, 2006).

Definisi-definisi yang telah ada semuanya benar, berdasarkan sudut pandang tertentu. Beragamnya definisi itu dapat disebabkan oleh keluasan wilayah kajian matematika itu sendiri dan sudut pandang yang digunakan. Namun yang menjadi ciri khas matematika yang tidak dimiliki pengetahuan lain adalah matematika merupakan abstraksi dari dunia nyata, menggunakan bahasa simbol, dan menganut pola pikir deduktif.

Untuk mempelajari matematika, selain mengetahui definisi matematika, akan lebih baik jika dikaji terlebih dahulu sifat-sifat atau karakteristik matematika itu sendiri. Menurut Suparni (2012), sifat atau karakteristik dari matematika yaitu obyek matematika abstrak, simbol yang kosong dari arti, kesepakatan dan pemikiran deduktif aksiomatik. Keberadaan simbol ini memberi peluang yang besar kepada matematika untuk digunakan dalam berbagai ilmu dan kehidupan nyata. Seperti contoh simbol 1, 2, 3, 4, dan seterusnya tidak memiliki makna apa-apa, akan tetapi ide bilangan 1, 2, 3 , dan seterusnya ada di alam ide seperti banyaknya benda yang dimiliki oleh seseorang berjumlah 2 dan sebagainya.

Kerja matematika pada umumnya di alam ide, oleh sebab itu objek kerja matematika bersifat abstrak. Abstraksi secara bahasa berarti proses pengabstrakan. Abstraksi sendiri dapat diartikan sebagai upaya untuk menciptakan definisi dengan jalan memusatkan perhatian pada sifat yang umum dari berbagai objek dan mengabaikan sifat-sifat yang berlainan. Objek abstrak matematika meliputi: objek langsung, yaitu fakta yang merupakan angka atau lambang bilangan, keterampilan yaitu kemampuan memberikan jawaban yang benar dan cepat, konsep adalah ide abstrak yang memungkinkan kita mengelompokkan benda-benda (objek) ke dalam contoh, aturan adalah objek yang paling abstrak. Sedangkan objek tidak langsung, meliputi: kemampuan menyelidiki, kemampuan memecahkan masalah, 
kemampuan belajar dan bekerja mandiri, bersikap positif terhadap matematika.

\section{Pendidikan Sedini Mungkin}

Anak adalah anugerah sekaligus amanah. Lebih dari itu, anak adalah investasi akhirat kedua orangtuanya. Rasulullah saw telah mengabarkan tiga jenis amal jariyah yaitu amal yang terus-menerus mengalir, salah satunya adalah anak yang shalih. Dalam hadits Nabi saw yang terkenal, disebutkan bahwa fitrah anak bisa berubah di tangan kedua orangtuanya. Ini sangatlah benar karena orangtua adalah lingkungan yang paling dekat dengan anak. Islam mengajarkan agar kita mendidik anak sedini mungkin. Mendidik anak bahkan sudah dimulai saat kita memilih pasangan hidup. Tidak lain karena pendidikan anak nantinya juga sangat tergantung pada kualitas pasangan hidup kita. Rasulullah saw bersabda, "Pilihlah ladang yang baik untuk menanam bibit (sperma) kalian.'Kemudian kita juga mulai mendidik anak ketika anak masih dalam kandungan. Demikian juga tentu saja setelah anak telah terlahir ke dunia. Kalimat pertama yang kita perdengarkan di telinga anak yang baru terlahir adalah kalimat-kalimat thayyibah berupa adzan dan iqamat. Pendek kata, jangan pernah menunda-nunda dalam mendidik anak. Lakukanlah sedini mungkin.

Dalam perspektif Islam, pendidikan yang diberikan kepada anak harus integral. Tidak hanya mendidik satu sisi saja lalu mengabaikan sisi yang lainnya. Anak harus dididik untuk menjadi manusia yang kuat iman dan ibadahnya serta bagus akhlaqnya, dan pada saat yang sama harus juga dididik untuk menjadi anak yang pintar, anak yang sehat, anak yang kuat, dan anak yang terampil.

\section{Mengenalkan Matematika Terintegrasi Islam kepada Anak Sejak Dini}

Mengenalkan dan mengajarkan matematika tidak hanya semata-mata mentransfer pengetahuan. Lebih dari itu, mengenalkan dan mengajarkan matematika sebaiknya ditambah dengan menanamkan ilmu keislaman, sikap terpuji dan akhlakul mahmudah.Menurut Abdussyakir dalam Fathani (2009) mengemukakan bahwa dampak positif pembelajaran matematika yang berkaitan dengan sikap terpuji atau akhlak mahmudah adalah sebagai berikut:

a. Sikap Jujur, Cermat dan Sederhana

Dalam matematika juga terdapat prinsip kejujuran. Dimana ketika kita melakukan proses dalam matematika dan tidak sesuai dengan prinsip atau teorema-teorema yang ada tentunya pekerjaan kita akan salah. Seperti contoh: Jika dalam matematika sudah menyepakati bahwa dalam basis sepuluh $3+3=6$, tentunya tidak boleh membenarkan 
$3+3=12$. Dengan dalih apapun seseorang tidak dapat membantah itu. Dalam mencari hasil tersebut kita juga harus cermat dan menggunakan metode yang sederhana.

b. Sikap Konsisten dan Sistematis terhadap Aturan

Matematika adalah ilmu yang didasarkan pada kesepakatan-kesepakatan yang sistematis dan dari kesepakatan itu seseorang yang bekerja dengan matematika harus menaatinya. Sebagai contoh kalau dalam matematika jumlah sudut dalam segitiga $=180^{\circ}$ dalam geometri euclid. Tentunya harus konsisten dan menaatinya untuk membuktikan kebenaran selanjutnya. Tidak hanya itu, pada bagian-bagian matematika juga sudah tersusun rapi secara sistematis seperti contoh pada konsep bilangan: bilangan kompleks di dalamnya terdapat bilangan real dan imajiner. Dalam bilangan real ada bilangan rasional dan irrasional. Di dalam bilangan rasional terdapat bilang bulat dan pecahan. Dari contoh tersebut matematika sangat sistematis dan konsisten dalam proses pengerjannya.

c. Sikap Adil

Dalam matematika terdapat prinsip keadilan dalam hal menyelesaikan sebuah persamaan. Seperti contoh: $2 x+5=15$, tentukan nilai $x$ !Dalam pengerjaannya terdapat prinsip keadilan. Operasi pada ruas kiri harus sama dengan ruas kanan.

d. Sikap Tanggung Jawab

Dalam matematika ada yang dinamakan proses pembuktian baik secara induktif ataupun deduktif. Setiap Pembuktian berasal dari sumber yang dapat dipertanggungjawabkan kebenarannya. Misalnya pembuktian teorema yang merujuk pada sebuah definisi yang kebenarannya telah disepakati. Teorema akan menimbulkan sebuah akibat yang disebut Lemma ataupun Corollary.

Jadi, dalam pembelajaran matematika sangat penting untuk membentuk pribadi yang berkualitas. Jika dapat mengintegrasikan Islam dari setiap konsep matematika tentunya akan lebih mudah mengembangkannya dalam setiap proses pembelajaran. Selain itu juga dapat menciptakan pembelajaran dengan mengkombinasi nilai-nilai Islam yang terkandung di setiap konsep matematika.

Berikut beberapa cara mengajarkan matematika terintegrasi Islam kepada anak sejak dini.

a. Menyebut nama Allah untuk memulai belajar .

b. Sebelum memulai belajar segala sesuatu termasuk matematika, ditradisikan diawali dengan membaca Basmalllah dan berdoa. Kemudian 
ketika mengakhiri setiap kegiatan ataupun aktivitas diupayakan ditutup dengan mengucap Alhamdulillah. Hendaknya selalu mengingatkan kepada anak betapa pentingnya mengatasnamakan Allah untuk segala aktivitas dan bersyukur kepada Allah, apa lagi ketika sedang menggali ilmu-Nya Allah termasuk mengenalkan matematika kepada anak.

c. Penggunaan kalender Hijriah dalam pengenalan konsep angka

Salah satu cara mengenalkan dan mengajarkan matematika terintegrasi Islam yaitu menggunakan kalender. Penggunaan kelender merupakan salah satu cara yang digunakan untuk mengenalkan anak tentang konsep angka. Berdasarkan penelitian yang dilakukan oleh Nurmainis dengan judul "Peningkatan Konsep Angka Melalui Permainan kalender di TK Islam Silaturahmi", diperoleh hasil bahwa permainan kalender merupakan alat permainan yang dapat meningkatkan pengenalan konsep angka pada anak dimana dari permainan ini anak akan lebih paham bagaimana konsep dari angka tersebut, serta anak akan lebih bisa mengurutkan, membilang, dan menghubungkan angka dengan bendabenda. Akan tetapi sebaiknya kalender yang digunakan adalah kalender Hijriah. Jadi, selain mengajarkan anak konsep angka juga dikenalkan jenis-jenis penanggalan. Salah satunya adalah penanggalanHijriah yaitu penanggalan dalam Islam. Sekaligus mengenalkan kepada anak hari-hari besar dalam Islam.

d. Penggunaan ornamen Islam dalam geometri

Contoh integrasi Islam dalam materi geometri, dalam membicarakan simetri dapat dicontohkan ornamen-ornamen masjid atau mushalla, dalam pembahasan bangun ruang dapat menampilkan ka'bah, dalam pembahasan bangun datar dapat menampilkan luas sajadah.

e. Penggunaan istilah dan nama-nama Islam dalam himpunan

Istilah dalam matematika sangat banyak. Diantara istilah tersebut dapat dinuansai dengan peristilahan dalam ajaran Islam, antara lain : penggunaan nama, peristiwa atau benda yang bernuansa Islam. Misalnya nama (Rasyid, Annisa, Afifah, Abdullah, dll), peristiwa (mewakafkan tanah dengan ukuran luas tertentu, kecepatan perjalanan ketika melakukan sa'i dari Saffa ke Marwa ketika ibadah haji), benda-benda (himpunan kitab-kitab suci, himpunan masjid).

f. Penggunaan metode bermain pada Aljabar

Bermain merupakan suatu kegiatan yang tepat bagi anak usia dini untuk bereksplorasi dan belajar. Bermain juga merupakan sarana yang amat diperlukan untuk proses berpikir karena menunjang perkembangan intelektual melalui pengalaman yang memperkaya cara berpikir 
anak.Menurut Vygotsky dalam Montolalu, dkk (2005), benar adanya hubungan erat antara bermain dan perkembangan kognitif.Mooney, et.al.juga menjelaskan bahwa anak belajar matematika melalui permainan dan eksplorasi seperti bercerita, mendengarkan cerita dan membuat cerita, bernyanyi, permainan imajinatif, maupun bermain peran.Kegiatan-kegiatantersebut lebih menarik dan menyenangkan. Anak terlibat dalam aktifitas-aktifitas yang mencakup dunianya (Fathani, 2009).Ali bin Abi Thalib mengatakan dalam sebuah ungkapannya yang masyhur : "Ajaklah anak bermain pada tujuh tahun pertama, disiplinkanlah anak pada tujuh tahun kedua dan bersahabatlah pada anak usia tujuh tahun ketiga." Selaras dengan ini, Ibnu Sina berkata, "Tujuh tahun pertama perlakukan anak seperti raja, tujuh tahun kedua seperti tawanan, dan tujuh tahun ketiga perlakukan anak seperti mitra." Ini artinya, sampai dengan usia 7 tahun adalah dunia bermain bagi anak. Salah satu contoh gambaran materi aljabar yang dapat dilakukan dengan bermain dan mengenalkan kepada anak mengenai Islam yaitu mengenai Sistem Persamaan Linear. Anak bermain membuat tasbih dari manikmanik warna hitam, putih, hijau, hitam, putih, hijau sebanyak 33 buah. Lalu tanyakan berapa jumlah manik-manik hitam, putih dan hijau yang dapat dibuat. Setelah tasbih selesai, jelaskan kepada anak apa kegunaan dari tasbih tersebut.

Masih banyak cara-cara yang dapat dilakukan untuk mengajarkan matematika terintegrasi Islam kepada anak. Hal yang terpenting adalah setiap pembelajaran hendaknya memberi manfaat kepada anak. Pengintegrasian konsep matematika dengan Islam sangat penting diterapkan sebagai cara pembentukan moral dan akhlak anak. Selain itu, perlu dikembangkan secara terus menerus analisis materi matematika dengan mengaitkan ayat-ayat yang terkandung dalam Al-Quran yang merupakan sumber dari segala sumber ilmu yang dapat diambil hikmah dan pelajarannya oleh setiap manusia melalui matematika.

\section{KESIMPULAN}

Kemampuan matematika seseorang sangat dipengaruhi penguasaan matematikanya sejak dini. Oleh karena itu, matematika perlu diperkenalkan dan diajarkan kepada anak sejak dini. Dalam pembelajaran matematika sangat penting untuk membentuk pribadi yang berkualitas. Jika dapat mengintegrasikan Islam dari setiap konsep matematika tentunya akan lebih mudah mengembangkannya dalam setiap proses pembelajaran. 
Beberapa cara mengajarkan matematika terintegrasi Islam kepada anak sejak dini yaitu menyebut nama Allah untuk memulai belajar, penggunaan kalender hijriah dalam pengenalan konsep angka, penggunaan ornamen Islam dalam geometri, penggunaan istilah dan nama-nama Islam dalam himpunan, dan penggunaan metode bermain pada aljabar.

\section{DAFTAR PUSTAKA}

Alwi, Hasan, dkk. (2002). Kamus Besar Bahasa Indonesia. Jakarta: Balai Pustaka.

Abdusysyakir. (2006). Ada Matematika dalam Al-Qur'an. Malang: UIN Malang Press.

Anggani, Sudono. (1995). Alat-alat Permainan dan Sumber Belajar Kanakkanak. Jakarta: Depdikbud.

Fathani, Abdul Halim. (2009). Matematika Hakikat dan Logika. Yogyakarta: Ar-Ruzz Media.

Gunawan, Heri. (2012). Pendidikan Karakter Konsep dan Implementasi. Bandung: Alfabeta.

Mooney, et al. (2009). Primary Mathematics: Teaching, Teory and Practice. Exeter: Learning.

Montolalu, dkk. (2005). Bermain dan Permainan Anak. Jakarta: Universitas Terbuka.

Nasution, Andi Hakim. (1982). Landasan Matematika. Bogor: Bhratara.

Soedjadi. R. (2010). Pengembangan Pendidikan Budaya dan Karakter Bangsa. Jakarta: Balitbang Kemendiknas

Suparni. 2012. Prosiding Seminar Nasional Penelitian, Pendidikan, dan Penerapan MIPA, Fakultas MIPA, Universitas Negeri Yogyakarta. "Pengembangan Karakter Bangsa Melalui Integrasi Nilai Keislaman dalam Pembelajaran Matematika". 